\title{
AKTIVITAS ANTIOKSIDAN DARI DAUN BINTANGUR (Calophyllum inophyllum L.) TERHADAP RADIKAL BEBAS DPPH (1,1 Difenil-2-pikrihidrazil)
}

\author{
Ahmad Purnawarman Faisal ${ }^{1}$, Pratiwi Rukmana Nasution ${ }^{2}$, Riza Fahlevi Wakidi ${ }^{3}$ \\ 1,2,3 Poltekkes Kemenkes Medan \\ Email Korespondensi : purn28@gmail.com
}

\begin{abstract}
ABSTRAK
Antioksidan adalah senyawa yang menghalangi reaksi oksidasi yang mengikat radikal bebas serta molekul reaktif. Bintangur mengandung saponin, tanin, flavonoid serta alkaloid. Dengan flavonoid, tujuan penelitian ini mencari tahu aktivitas antioksidan ekstrak etanol kepada radikal bebas $\mathrm{DPPH}$, serta parameter $\mathrm{IC}_{50}$ mempunyai aktivitas antioksidan tertinggi. Gunakan etanol untuk maserasi serbuk daun bintangur. Menganalisis kandungan metabolit sekunder dalam ekstrak etanol. Gunakan spektrofotometer menguji aktivitas antioksidan ekstrak yang diperoleh terhadap radikal bebas DPPH di panjang gelombang $517 \mathrm{~nm}$, serta tentukan nilai $\mathrm{IC}_{50}$. Rutin dipakai untuk kontrol positif di penelitian ini. Hasil tiga penelitian memperlihatkan bahwa nilai $\mathrm{IC}_{50}$ ekstrak etanol masing-masing adalah $65,49 \mathrm{ppm}, 65,76 \mathrm{ppm}$, dan 65,76 ppm. Nilai $\mathrm{IC}_{50}$ rata-rata adalah $55,67 \mathrm{ppm}$.
\end{abstract}

Kata kunci : Bintangur, Calophyllum inophyllum L., Antioksidan, DPPH 


\title{
ANTIOXIDANT ACTIVITY OF BINTANGUR LEAVES (Calophyllum inophyllum L.) AGAINST DPPH FREE RADICAL (1,1 Diphenyl-2-picrihydrazil)
}

\begin{abstract}
Antioxidants are compounds that can inhibit oxidation reactions by binding to free radicals and highly reactive molecules. Bintangur contains saponins, tannins, flavonoids and alkaloids. In the presence of flavonoids, the purpose of this study is to understand the antioxidant activity of ethanol extracts against DPPH free radicals, and the IC 50 parameter has the highest antioxidant activity. Use ethanol to macerate Bintangur leaf powder. Analyze the content of secondary metabolites in ethanol extracts. Use a spectrophotometer to test the antioxidant activity of the obtained extract against DPPH free radicals at a wavelength of $517 \mathrm{~nm}$, and determine the $I C_{50}$ value. Routine was used as a positive control in this study. The results of three repeated studies showed that the $I C_{50}$ values of the ethanol extract were $65.49 \mathrm{ppm}, 65.76 \mathrm{ppm}$, and $65.76 \mathrm{ppm}$, respectively. Average $I_{50}$ value is $55.67 \mathrm{ppm}$.
\end{abstract}

Keywords: Bintangur leaf, Calophyllum inophyllum L., Antioxidant, DPPH

\section{PENDAHULUAN}

Salah satu tumbuhan obat yang dimana terdapat sebesar $15,7 \%$ dari dapat dimanfaatkan ialah Bintangur masyarakat Indonesia yang menyimpan (Calophyllum inophyllum L.) yang obat tradisional berbahan alam. merupakan tanaman khas dan sudah sejak lama digunakan masyarakat sebagai obat gosok untuk luka. (Fajriaty et al, 2018). Dewasa ini pemanfaatan pengobatan tradisional semakin marak karena kecenderungan masyarakat untuk lebih memilih bahan alam, ini dikuatkan berdasarkan Riset Kesehatan Dasar (RISKESDAS) tahun 2013 
pendonor elektron dan juga senyawa yang bisa menghalangi oksidasi dengan bergabung dengan radikal bebas serta molekul yang aktif, dan menghambat rusaknya sel. (Winarsi 2007). Antioksidan dibagi menjadi antioksidan alami serta antioksidan buatan menurut sumbernya. (Dalimartha dan Soedibyo 1999).

Uji menentukan aktivitas antioksidan penangkapan radikal ialah metode DPPH sebagai radikal bebas stabil yang ditetapkan secara spektrofotometri. Metode DPPH memberi data reaktivitas senyawa diuji dengan hal radikal stabil. Difenil pikrilhidrazil (DPPH) mengakibatkan serapan kuat di panjang gelombang 517 $\mathrm{nm}$ diiringi reaksi reduksi dari senyawa antioksidan (Pokorny et al. 2001).

Penelitian oleh Shanmughpriya (2016) menyatakan ditemukan kandungan fenol dalam daun Bintangur mempunyai keahlian menghalangi pertumbuhan berbagai mikroba seperti Staphylococcus aureus, Eschericia coli dan Mycobacterium sp dan jamur Candida tropicalis.Kemudian Monica Pudji Astuti (2018) menyatakan bahwa tidak ditemukan adanya zona hambat pada ekstrak daun Bintangur serta tidak mempunyai aktivitas antifungi terhadap pertumbuhan jamur Candida albicans, sedangkan bagi antioksidan sepengetahuan peneliti masih belum banyak diteliti, alhasil peneliti tertarik mengadakan penelitian dengan judul "Identifikasi Metabolit Sekunder dan Aktivitas Antioksidan dari Daun Bintangur (Calophyllum inophyllum L.) terhadap Radikal Bebas DPPH (1,1 Difenil-2-pikrihidrazil).

\section{METODE PENELITIAN}

MATERIAL

Bahan utama penelitian ini yakni daun bintangur, etanol 95\% dalam maserasi, $D P P H$. Alat penyarian adalah bejana untuk maserasi, spektrofotometri, kuvet, labu takar. Peralatan lainnya yang dipakai yakni neraca, waterbath, beaker glass, pipet volume, mikro pipet, cawan penguap.

\section{Rancangan Penelitian}

Identifikasi tumbuhan dilakukan guna memutuskan kebenaran sampel bintangur sesuai karakteristik tumbuhan bintangur.

1) Persiapan Penelitian

Daun bintangur yang digunakan adalah batang yang telah kering dari daerah Medan, Sumatera Utara. Simplisia diletakkan di wadah kering https://doi.org/10.33759/jrki.v4i1.200 
yang tertutup, kemudian bisa dipakai penelitian.

2) Pembuatan Ekstrak Etanol 95\% Daun

Bintangur

Sampel daun segar bintangur dikeringkan dan dipotong kecil-kecil dan dikeringkan. Setelah kering diekstraksi memakai metode maserasi dengan pelarut etanol $95 \%$ dengan durasi 4 hari. Hasil maserasi diuapkan memakai rotary evaporator yang hasilnya didapatkan ekstrak etanol.

3) Persiapan larutan $D P P H 0,45 \mathrm{mM}$

Larutan pereaksi ialah larutan DPPH $0,45 \mathrm{mM}$. diproduksi dengan mengukur $0,01774 \mathrm{mg}$ serbuk DPPH lalu dimasukkan ke labu takar $100 \mathrm{ml}$ dimasukkan metanol p.a. ke labu takar hingga tanda batas, alhasil didapatkan konsentrasi $0,45 \mathrm{mM}$ yang diukur kepada BM DPPH sejumlah 394,32 $\mathrm{g} / \mathrm{mol}$.

4) Penentuan operating time

Dilakukan terhadap ekstrak etanol daun bintangur dengan cara membuat larutan stok terlebih dahulu. Larutan stok ekstrak Daun bintangur dibuat memakai konsentrasi 500 ppm. Dengan mengukur 0,0250 gram ekstrak kental dengan seksama lalu dilarutkan memakai metanol p.a. hingga larut serta diletakkan ke labu ukur $50 \mathrm{ml}$, kemudian masukkan metanol p.a ke tanda batas. Dari larutan stok diencerkan lagi menjadi 100 ppm kemudian dipipet $4 \mathrm{ml}$ serta $1,0 \mathrm{ml}$ larutan DPPH $0,45 \quad \mathrm{mM}$ untuk mendapatkan absorbansinya. Operating time ditentukan juga terhadap rutin 10 ppm dengan cara yang sama. Penentuan operating time diadakan di panjang gelombang maksimal memakai interval 5 menit hingga diperoleh absorbansi konstan, serta tidak ada penurunan absorbansi (Purwanto 2010).

5) Penentuan panjang gelombang maksimum DPPH

Uji aktivitas antioksidan ekstrak etanolik diadakan guna memutuskan panjang gelombang maksimal dalam larutan DPPH, tahapan uji ini yakni : $1,0 \quad \mathrm{ml}$ larutan $\mathrm{DPPH} \quad 0,45 \mathrm{mM}$ ditambahkan 4,0 $\mathrm{ml}$ metanol p.a, dikocok sampai homogen serta diamati serapan di rentang 500-525 nm memakai blanko metanol p.a.

6) Pengujian aktivitas Antioksidan

Ekstrak etanol daun bintangur masing-masing dihitung 0,0250 gram, lalu dilarutkan memakai metanol p.a hingga larut serta diletakkan ke labu ukur $50 \mathrm{ml}$, lalu ditambah metanol p.a hingga tanda batas, sehingga bisa didapat konsentrasi 500 ppm, maka 
larutan ini dinamakan larutan stok. Konsentrasi larutan uji dibuat dengan memipet larutan stok untuk mendapat 5 seri konsentrasi. Pembuatan larutan stok rutin dilakukan dengan cara menimbang 0,0125 gram rutin lalu dilarutkan memakai metanol p.a hingga larut serta diletakkan ke labu ukur $25 \mathrm{ml}$, kemudian ditambahkan metanol p.a hingga tanda batas dan selanjutnya dibuat 5 seri konsentrasi yang pembacaan absorbansi adalah 0,2-0,8. Tiap konsentrasi larutan uji dipipet sejumlah 4,0 $\mathrm{ml}$, lalu ditambah $1 \mathrm{ml}$ larutan pereaksi DPPH 0,45 $\mathrm{mM}$ dalam vial, serta didiamkan 30 menit lalu diamati absorbansinya di panjang gelombang maksimal yang sudah diputuskan (517 nm). Percobaan diadakan 3 kali pengulangan juga pengamatan kepada larutan kontrol dari $4 \mathrm{ml}$ metanol ditambah $1 \mathrm{ml}$ DPPH 0,45 $\mathrm{mM}$.

\section{HASIL DAN PEMBAHASAN \\ Pembuatan Ekstrak Etanol Daun Bintangur}

Daun bintangur sejumlah 5600 gr dikeringkan di suhu $40^{\circ} \mathrm{C}$ serta didapatkan 820 gr daun kering dengan rendemen 14,64 \% b/b. Pengeringan daun bintangur dilakukan pada suhu $40^{\circ} \mathrm{C}$ dalam oven, apabila pengeringan suhu lebih dari $50^{\circ} \mathrm{C}$ dikhawatirkan terjadi kerusakan pada kandungan senyawa-senyawa aktif pada simplisia. Kelebihan pengeringan menggunakan oven adalah suhu bisa diatur sesuai keinginan. Ekstrak etanol yang didapatkan sebesar 42,88 gram.

\section{Penentuan Operating Time DPPH}

Pengukuran panjang gelombang maksimum DPPH di penelitian ini yakni $517 \mathrm{~nm}$ dengan absorbansi sebesar 0,834. Grafik panjang gelombang maksimum DPPH 0,45.

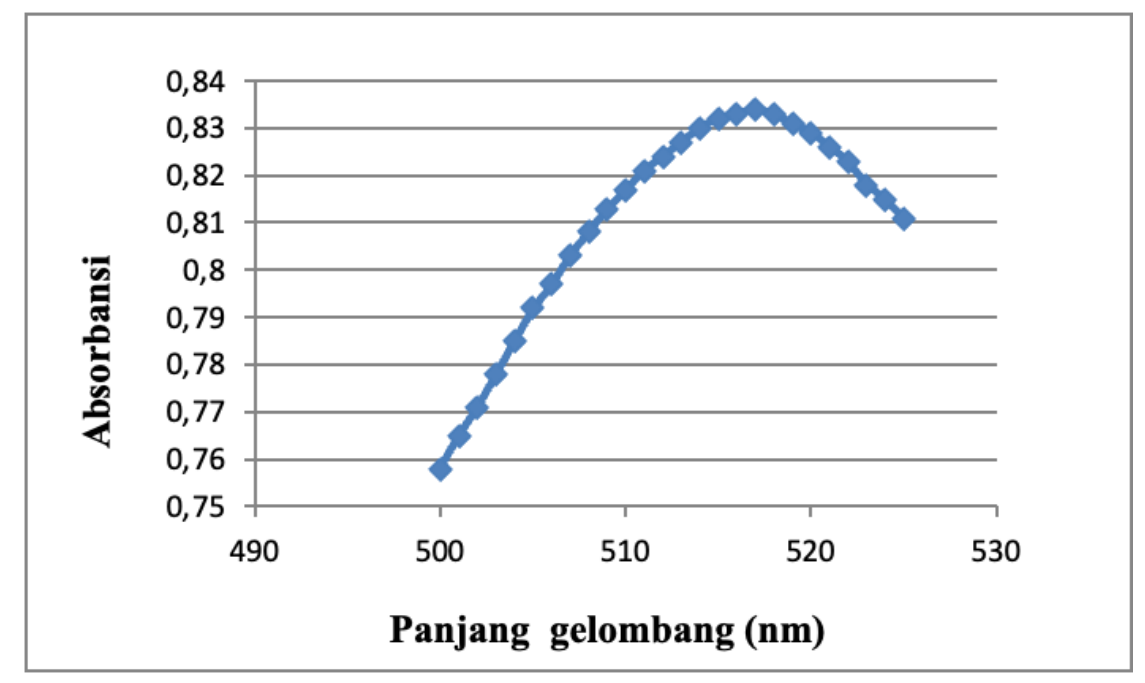


Gambar 1 .Kurva panjang gelombang maksimum (nm)

Operating time digunakan guna menentukan lamanya pengukuran yang stabil dalam meredam radikal bebas DPPH. Hasil pengukuran operating time waktu stabil diawal di menit ke-20 hingga ke-40. Penelitian ini memakan waktu 30 menit pada operating time.

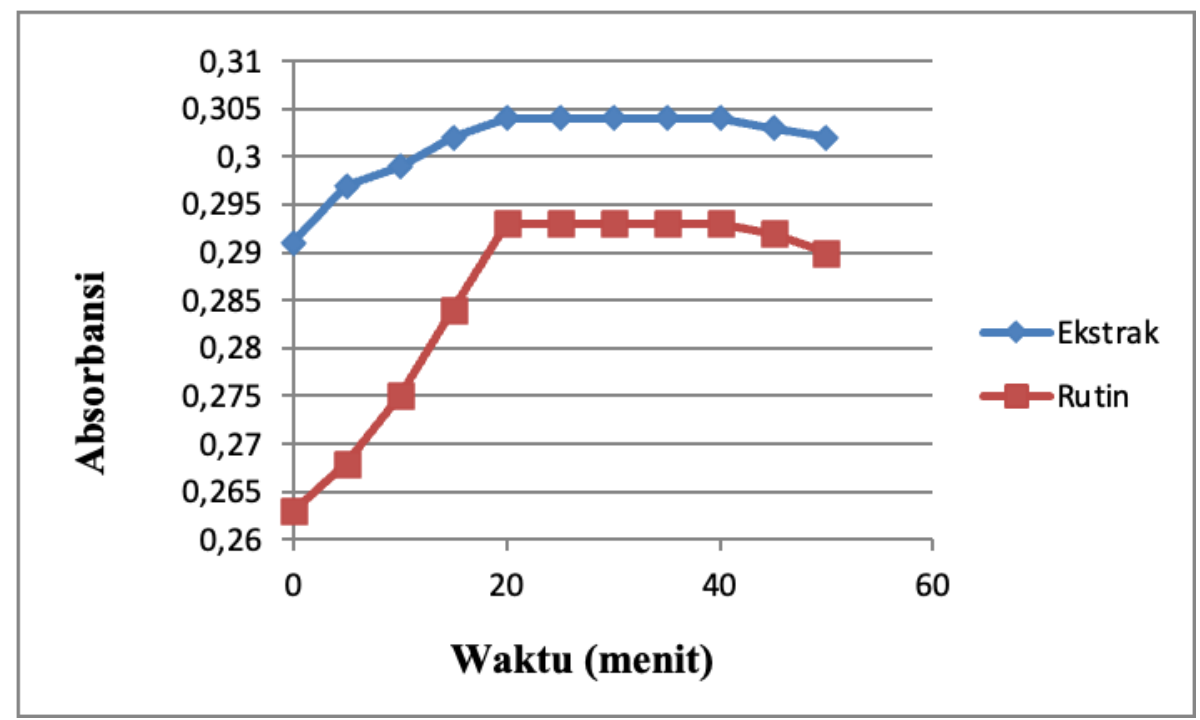

Gambar 2. Grafik operating time

Uji
Aktivitas
Antioksidan
Daun
Hubungan konsetrasi larutan uji
Bintangur
terhadap peredaman DPPH bisa diketahui di tabel dibawah

Tabel 1. Hubungan konsentrasi larutan uji terhadap peredaman DPPH

Rata-rata peredaman

NO Larutan uji Konsentrasi (ppm)

$(\%)$

\begin{tabular}{ccccc}
\hline & & $\mathrm{R} 1$ & $\mathrm{R} 2$ & $\mathrm{R} 3$ \\
\hline $1 . \quad$ Ekstrak & 100 & 63,19 & 62,95 & 63,30 \\
& 80 & 52,88 & 53,12 & 52,76 \\
& 60 & 46,64 & 46,76 & 46,52 \\
& 40 & 38,72 & 39,49 & 38,25 \\
& 20 & 20,38 & 20,86 & 20,62
\end{tabular}




\begin{tabular}{ccc}
\hline 2. Rutin & 10 & 66,11 \\
8 & 63,71 \\
6 & 49,58 \\
4 & 38,21 \\
2 & 19,16 \\
\hline
\end{tabular}

Secara keseluruhan aktivitas peredaman radikal yang kuat adalah rutin ini diakibatkan karena rutin ialah senyawa murni dan ekstrak etanol ialah senyawa murni. Rutin dipakai untuk pembanding di metode DPPH ini disebabkan rutin telah diketahui sebagai glikosida flavonoid yang telah terbukti antioksidannya.

Berdasarkan data konsentrasi uji dan persen peredaman dapat disimpulkan bahwa terdapat hubungan berbanding lurus antara konsentrasi dengan persen peredaman, yaitu makin tinggi konsentrasi larutan uji makin tinggi juga persen peredamannya. Pengujian prosentase peredaman larutan uji ekstrak etanol dilakukan 3 replikasi tiap konsentrasi..

Metode DPPH membagikan informasi reaktivitas senyawa yang diuji memakai suatu hal radikal stabil. Proses peredaman radikal bebas oleh senyawa antioksidan bisa diketahui dari perubahan warna violet larutan DPPH jadi warna kuning diiringi turunnya serapan panjang gelombang $517 \mathrm{~nm}$. Perubahan warna tersebut memperlihatkan aktivitas antioksidan yang bisa diketaui persentase peredamannya. Radikal bebas DPPH mengambil atom hidrogen yang ada di senyawa.

Proses perubahan warna akibat berkurangnya ikatan rangkap terkonjugasi pada DPPH. Ini terjadi ketika elektron ditangkap oleh antioksidan, dan elektron tidak memiliki kesempatan untuk beresonansi. Saat elektron tidak berpasangan berubah jadi elektron berpasangan dengan tambahan donor hidrogen, radikal bebas terjadi pada antioksidan, alhasil membentuk DPPH yang stabil. Aktivitas scavenging radikal bebas dinyatakan sebagai persentase pengurangan DPPH, dikatakan sebagai konsentrasi yang mengakibatkan hilangnya 50\% aktivitas DPPH (IC50). Nilai IC $_{50}$ adalah ukuran yang baik dari efisiensi antioksidan untuk senyawa murni. Pengujian absorbansi peredaman radikal dilakukan 
pembuatan seri konsentrasi terlebih dahulu pada ekstrak dan masing-masing fraksi, kemudian ditambahkan DPPH pada setiap seri konsentrasi dan dibaca absorbansinya dengan panjang gelombang 517. Pembacaan absorbansi pada penelitian ini dilakukan dengan waktu operating time yang telah di tentukan dan dihitung persen peredamannya.

Berdasarkan data persen peredaman dari ekstrak etanolik, setiap fraksi serta rutin, lalu data dianalisis probit serta dihitung nilai $\mathrm{IC}_{50}$ memakai persamaan regresi linier menggunakan rumus $\mathrm{Y}=\mathrm{a}+\mathrm{bx}$. Nilai $\mathrm{IC}_{50}$ ialah angka yang memperlihatkan konsentrasi sampel uji untuk bisa meredam DPPH sejumlah 50\%. Makin kecil nilai $\mathrm{IC}_{50}$, makin efektif sebagai antioksidan, kemudian dihitung nilai persen koefisien variasi dengan simpangan baku relatif ataupun koefisien variasi $2 \%$, yang didapatkan memakai metode mengetahui kedekatan hasil sampel kepada nilai nominal serta presisi. Nilai $\mathrm{IC}_{50}$ dari larutan uji ekstrak dapat dilihat pada gambar grafik dibawah ini.

Tabel 2. Nilai $\mathrm{IC}_{50}$

\begin{tabular}{clc}
\hline NO & \multicolumn{1}{c}{ Larutan uji } & Nilai IC50 \pm SD \\
\hline 1 & R1 & $65,49 \pm 0,156$ \\
2 & R2 & $65,76 \pm 0,641$ \\
3 & R3 & $65,76 \pm 0,091$ \\
5 & Rutin & $5,796 \pm 0,027$ \\
\hline
\end{tabular}

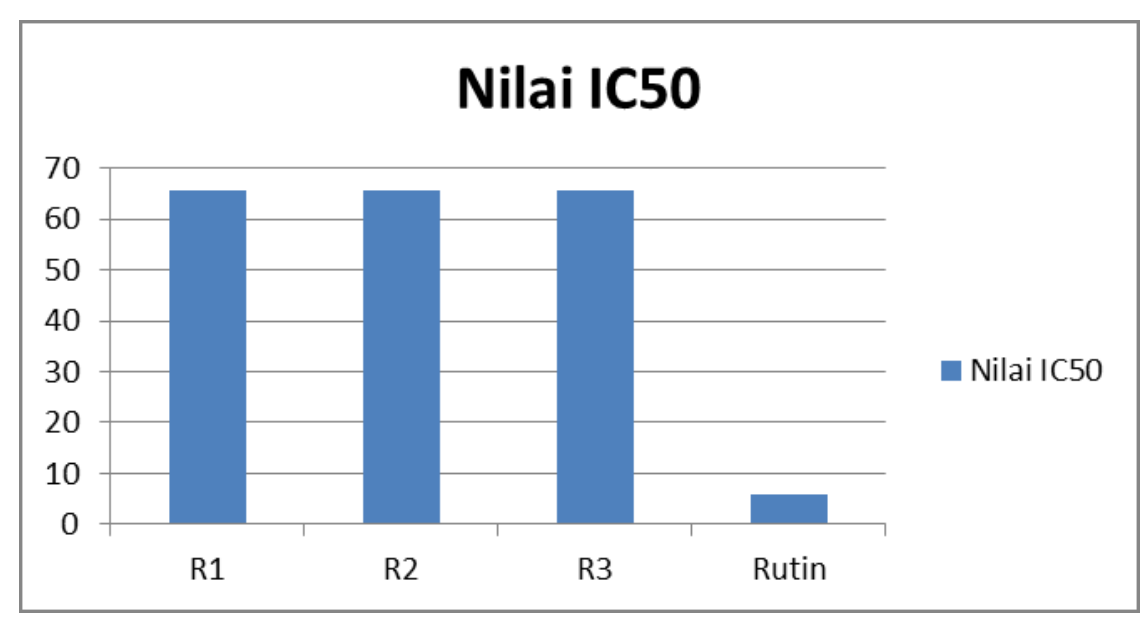

Gambar 3. Kurva panjang gelombang maksimum (nm) 
Hasil perhitungan nilai $\mathrm{IC}_{50}$ diketahui bahwa ekstrak etanol daun bintangur memiliki nilai $\mathrm{IC}_{50}$. Hal tersebut mengartikan bahwa ekstrak mengandung senyawa aktif golongan flavonoid yang berpotensial meredam radikal bebas dengan kadar senyawa aktif pada. Rutin dipakai jadi pembanding di metode DPPH disebabkan rutin telah diketahui sebagai glikosida flavonoid yang terbukti aktivitas antioksidannya.

\section{KESIMPULAN}

Kesimpulan penelitian ini yakni :

1. Rendemen ekstrak daun bintangur basah terhadap simplisia kering sebesar 14,64\%. Dan ekstrak terhadap simplisia kering 5,22\%

2. Pengaruh pemberian fraksi ekstrak etanol daun bintangur terhadap aktivitas antioksidan kepada radikal DPPH berturut-turut Nilai IC50 yaitu 65,49 ppm, 65,76 ppm, dan $65,76 \mathrm{ppm}$.

\section{UCAPAN TERIMAKASIH}

Peneliti menyampaikan terima kasih keseluruh pihak yang sudah membantu penelitian ini :

1. Direktur Poltekkes Kemenkes Medan
2. Kepala Unit Penelitian dan Pengabdian Masyarakat Poltekkes Kemenkes Medan

3. Ketua Jurusan Farmasi Poltekkes Kemenkes Medan

4. Tim Peneliti

\section{DAFTAR PUSTAKA}

Abbas AK and Lichtman AH. 2002., Cellular and molecular immunology, 6th edition. Philadelphia: Elsevier Science.

Ahmad N. 2006. Fitokimia II. Fakultas Farmasi. Universitas Muslim Indonesia

Anonim. 2008. Direktorat Obat Asli Indonesia. Badan POM RI, Jakarta

"Dalimartha, S. dan Soedibyo, M. 1999, Awet Muda Dengan Tumbuhan Obat dan Diet Suplemen.,Trubus Agriwidya, Jakarta. hal. 36-40

Fajriaty, I., Hariyanto, I. H., Andres, A., \& Setyaningrum, R. (2018). Skrining Fitokimia dan Analisis Kromatografi Lapis Tipis dari Ekstrak Etanol Daun Bintangur (Calophyllum soulattri Burm. F.). Jurnal Pendidikan Informatika dan Sains, 7(1), 54-67." 
Flora E. 2011. Tanaman Obat Indonesia untuk pengobatan Herbs Medicine Herba Tanaman Obat,Indonesia

“Gandjar I.G. dan Rohman A. 2007.

Kimia Farmasi Analisis.

Cetakan III. Pustaka Pelajar; Yogyakarta

Pokorny, J., Yanishlieva, N., \& Gordon, M. H. (Eds.). (2001). Antioxidants in food: practical applications. CRC press.
Shanmugapriya, A., Kalaiarasi, G., Kalaivani, P., Dallemer, F., \& Prabhakaran, R. (2016). CTDNA/BSA protein binding and antioxidant studies of new binuclear Pd (II) complexes and their structural characterisation. Inorganica Chimica Acta, 449, 107-118”

Winarsi, H. (2007). Antioksidan alami \& radikal bebas. Pustaka Poltekkes Padang, Padang 